\title{
A SEROPREVALENCE STUDY OF BRUCELLOSIS IN GOATS AT KAFRELSHEIKH GOVERNORATE, EGYPT
}

\author{
Yasser Mohamed Abdel Rahman Ghanem \\ Department of Animal Medicine, Faculty of Veterinary Medicine, Kafrelsheikh \\ University, Kafrelsheikh 33516, Egypt.
}

\begin{abstract}
A random survey to study the seroprevalence of caprine brucellosis has been carried out during January to May 2011 in Matbool village of Kafrelsheikh Governorate, Egypt. A total number 276 sexually mature goats blood sera were collected from randomly sporadic 12 flocks of accessible unvaccinated goats to be analyzed. Rose Bengal Plate Test (RBPT) and indirect ELISA (I-ELISA) were used to screen all serum samples. On herd level, out of 12 flocks examined, 8 (66.66\%) and 9 (75.0\%) flocks were seropositive by RBPT and IELISA respectively. On animal level, overall seroprevalence of brucellosis among examined goats were $6.16 \%(n=17)$, and $7.97 \%$ $(n=22)$ by $R B P T$ and I-ELISA respectively. A non significant differences were found between the examined goats in relation to sex $(p=0.8)$. As out of examined 112 male goats sera, $5.36 \%(n=6)$ and $7.14 \%(n=8)$ by RBPT and I-ELISA respectively, while for 164 female goats sera, $6.7 \%(n=11)$, and $8.54 \%(n=14)$ by RBPT and I-ELISA respectively. These results indicate high specificity of I-ELISA for brucella diagnosis in comparison to RBT.
\end{abstract}

Keywords: caprine, brucellosis, serology, prevalence, Rose Bengal test, ELISA. 


\section{INTRODUCTION}

Brucellosis is a zoonosis that exists worldwide and is more or less endemic within most countries of Africa (Chukwu, 1985; Anonymous, 1986; Akakpo and Bornarel, 1987). For several decades it has been recognized as a significant public health problem in the Middle East and recent reports suggested that its incidence is increasing in both ruminants and humans (Benkirane, 2006; and Refai, 2002) and that currently applied control measures may not be capable of reducing the levels of infection in ruminants (Hegazy et al., 2009).

Nearly all livestock animals are raised by traditional methods of husbandry in small herd/flocks with other species (sheep, cattle and/or camels) in small settlements with restricted movements except for grazing or water sources. There are six different species of brucella, where cattle, goats, sheep, pigs, buffaloes, camels, reindeer and, less frequently, other mammals are affected by brucellosis (Charters, 1980). Small ruminant brucellosis is mostly caused by Brucella meltensis (Omer et al., 2002). Brucella ovis is also an important cause of orchitis and epididymitis in sheep but it is not recognized as a cause of natural infection in goats (Smith and Sherman, 1996). In goats, excretion of the organisms from the vagina is prolonged and copious (2 to 3 months generally).

The spread of infection between flocks generally follows the movement or gathering of infected animals. Intermingling of flocks may occur under conditions of husbandry and also in static village flocks where animals are taken daily for grazing on common pastures. 
Brucellosis has been reported in small ruminants from different parts of the world. Prevalence rates of $5.0 \%$ in goats in south provinces in Egypt (Montasser et al., 2011), $1.5 \%$ in goats in Sudan (Abdala, 1966) ; $2.8 \%$ in goats in Kenya (Waghela, 1976) ; $5.29 \%$ in goats in Somalia (Falade and Hussein, 1997) ; $3.8 \%$ in goats in Eritrea (Omer et al., 2000); $4 \%$ in goats eastern Sudan (El-Ansary et al., 2001); $4.75 \%$ in goats in Nigeria (Shehu et al., 1999); $1.3 \%$ in goats in Ethiopia (Ayele, 1991).

In order to be able to screen a large number of animals, the diagnostic tests should be inexpensive, easy to perform, rapid, highly sensitive and fairly specific, and suitable for screening individual animals (Nielsen, 2002). Tests currently used for the serological diagnosis of brucella melitensis infections in goats were initially developed for the diagnosis of B. abortus infections in cattle. The diagnosis can be directly by isolation of Brucella, or indirectly by the detection of immune response against its antigens. The rose bengal test (RB) are the most widely used test for the serological diagnosis of sheep brucellosis (Farina, 1985; and MacMillan, 1990). They are currently the official tests used in member states of the European Union (Council Directive 91/68/EEC).

However, recent results showed that the sensitivity of the classical RB antigen prepared with B. abortus biovar 1 (A-dominant) was adequate for diagnosing ovine and caprine populations infected with the M dominant B. Melitensis biovar 1 (Blasco et al., 1994b), and is internationally recommended for the screening of brucellosis in small 
ruminants (Joint FAO/WHO, 1986); Garin-Bastuji and Blasco, 1997). The outer membrane of smooth Brucella is composed of phospholipids, proteins and lipopolysaccharide (smooth lipopolysaccharide, S-LPS). The S-LPS is the immunodominant antigen. Most serological tests, particularly those using whole-cell suspensions as antigen (such as RB, $\mathrm{CF}$ ), as well as ELISA, have been developed to detect antibodies to this antigen (Díaz et al., 1968a). The large majority of EIAs in use for brucellosis diagnosis are indirect ELISAs (iELISA). (Gorrell et al., 1984); Rylatt et al., 1985); Sutherland et al., 1986); MacMillan, 1990); Greiser-Wilke et al., (1991); Nielsen et al., 1991); Marín et al., 1999); Nielsen et al., 2000). (iELISAs) have been developed using more or less purified S-LPS as the antigen and have been reported to be at least as sensitive and specific as the combination of both RB and CF tests for the diagnosis of brucellosis in ruminants (Alonso-Urmeneta et al., 1998).

Therefore, a combination of the two tests (RBPT and I-ELISA) shows a degree of sensitivity and specificity which appears sufficient to detect infected animals, and removal of those animals appears to contribute to disease control. The objective of this study was, therefore, to determine the prevalence of goat brucellosis in a village at kafrelsheikh governorate, Egypt.

\section{MATERIAL AND METHODS}

\section{1- Study Area:}

This study was conducted during the period from January to May 2011 in Matbool village, Kafrelsheikh Governorate, Egypt. 


\section{2- Study Animals:}

A total number of unvaccinated 276 goats were examined in this study constituting 12 herd flocks (112 males and 164 females) of animals older than 6 months. (The number of heads per flock ranged between 18 31). Information of each herd sampled was obtained including its location, herd size, sex, age, health status, history of abortion, wheather reared individually or with other species.

\section{3- Blood sample:}

Blood samples were collected from unvaccinated 276 goats of both sexes. A $10 \mathrm{ml}$ blood samples were collected using vacutainer tubes with a separate needle for each blood sample and each sample was allowed to clot and transferred onto ice box as quickly as possible to the laboratory of the central laboratory of Faculty of Veterinary Medicine, Kafrelsheikh University. The sera were separated by centrifugation at $2000 \mathrm{rpm}$ for 10 min and each serum sample was aspirated in an eppendorf tube using a pasteur pipette, labeled and stored at $-20^{\circ}$ until testing

\section{4-Serological tests:}

All collected sera were screened for antibodies against Brucella by the Rose Bengal plate Test (RBPT), and the Indirect Enzyme Linked Immunosorbant Assay (I-ELISA) (SERELISA) as described by the manufacturers

\subsection{Rose Bengal Plate Test (RBPT):}

Rose bengal antigens were obtained from $\boldsymbol{C Z}$ Veterinaria, S.A. SPAIN (Batch number, 07014). Antigens stored between +2 and $+8^{\circ} \mathrm{C}$, and protected from light. Test procedure according to the manufacturer 
as follows: A control serum was tested one day before the test to verify the test conditions. The sera and antigens were removed from the refrigerator and left at room temperature $\left(+22^{\circ} \mathrm{C} \pm 4^{\circ} \mathrm{C}\right)$ for at least 30 minutes before the test was performed. Briefly, $30 \mu 1$ of sera samples were dispensed onto the white 12 well ceramic plate, and $30 \mu 1$ of RBPT antigen using a micropipette was mixed with the sera using tooth picks and shaken for 4 min using an electric shaker in single direction before examined for agglutination. For interpretation of the results, both positive and negative controls were employed. Results of RBPT were interpreted as negative, doubtful and positive (no visible agglutination regarded as negative, slight agglutination as doubtful, clear visible agglutination and rim formation as positive).

\section{Indirect Enzyme Linked Immunosorpent Assay (I-ELISA):}

According to the procedure of the manufacturer (Synbiotics Europe "SERELISA ${ }^{\circledR}$ Brucella OCB Ab Mono Indirect" 2, Rue A. Fleming 69007 LYON - FRANCE; Batch number, 8 SBRU30CB 08), indirect ELISA was performed. Kit uses an indirect immunoenzymatic technique allowing the detection of Brucella lipopolysaccharide (LPS) antibodies in individual serum samples of B. aborus and B. melitensis. Serum and ELISA kit are allowed at room temperature for at least 30 minutes before use. The reaction is composed of the following steps: Each individual serum sample is placed in a well sensitized with the Brucella LPS. Antibodies present in the sample bind to the bacterial antigen coated to the wells. A $100 \mu$ of the diluted negative control (N) 
distributed in wells A1 and A2, and $100 \mu$ of the diluted positive control (P) in wells B1 and B2. Dilute the samples at 1:10 in sample diluent (SD) in a dilution plate. Dilute again at 1:10 directly in sample diluent (SD). Distribute $100 \mu \mathrm{l}$ in each well, cover the wells with adhesive film, mix by gentle shaking the plate manually and incubate of the plate for 1 hour $( \pm 5 \mathrm{~min})$ at $+37^{\circ} \mathrm{C}\left( \pm 3^{\circ} \mathrm{C}\right)$. Dilute the concentrated washing solution (W) 1:10 in distilled water. Carefully remove the adhesive film and wash 4 times (300ul/well). Dilute the concentrate (CJ) 1:200 in the conjugate diluent (CD). Add $100 \mu 1$ of diluted conjugate to all wells and cover with a new piece of adhesive film. Incubate 30 minutes $( \pm 5 \mathrm{~min})$ at $+37^{\circ} \mathrm{C}( \pm$ $3^{\circ} \mathrm{C}$ ). Carefully remove the adhesive film and wash 4 times. Add $100 \mu \mathrm{l}$ of buffered peroxidase substrate (PS) per well. Do not cover with adhesive film at this stage. Mix by gentle shaking the plate manually. Incubation of substrate for $30 \mathrm{~min} . \pm 5 \mathrm{~min}$ at laboratory temperature $\left(+20^{\circ} \mathrm{C} \pm 5^{\circ} \mathrm{C}\right)$, shielded from light. Add $50 \mu \mathrm{l}$ of stop solution (S) per well. Mix by gentle shaking the plate manually. Measure the optical density (OD) monochromatically at $450 \mathrm{~nm}$ and/or bichromatically at $630 \mathrm{~nm}$. The results of each test run are valid if: OD P $\geq 0.5$ and OD $\mathrm{N}<$ 0.3 The presence or the absence of antibodies against LPS of Brucella is determined by comparing the Optical Densities (OD) to the threshold values obtained from the positive control. Positive threshold value in index $=0$, Sample index $=0.50 \times$ (sample OD $-0.6 \times$ OD P). Any sample presenting an index $\leq 0$ is considered as positive. Any sample presenting an index $<0$ is considered as negative. 


\section{RESULTS}

\section{Seroprevalence results:}

On herd level, out of 12 flocks examined, $8(66.66 \%)$ and 9 (75.0\%) flocks were seropositive by RBPT and I-ELISA respectively (Table 1 and 2). On animal level, overall seroprevalence of brucellosis among examined 276 goats were $6.16 \%(n=17)$, and $7.97 \%(n=22)$ by RBPT and I-ELISA respectively. A non significant differences were found between the examined goats in relation to sex $(\mathrm{p}<0.8)$. As out of examined 112 male goats sera, 5.36\% $(n=6)$ and $7.14 \%(n=8)$ by RBPT and I-ELISA respectively, while for 164 female goats sera, $6.7 \%(n=11)$, and $8.54 \%(\mathrm{n}=14)$ by RBPT and I-ELISA respectively (Table 3$)$. The obtained data had been analyzed statistically using chi-square test according to Snedecor and Cochran, (1980).

Table (1): Seroprevalence of caprine brucellosis on herd level in Matbool village of Kafrelsheikh governorate.

\begin{tabular}{|c|c|c|c|c|c|c|c|c|c|c|c|c|}
\hline \multirow{3}{*}{ District } & \multirow{2}{*}{\multicolumn{4}{|c|}{ Species herd No. Numbers tested }} & \multicolumn{4}{|c|}{ RBPT Positive } & \multicolumn{4}{|c|}{ I-ELISA Positive } \\
\hline & & & & & \multicolumn{2}{|c|}{ M. } & \multicolumn{2}{|c|}{ F. } & \multicolumn{2}{|c|}{ M. } & \multicolumn{2}{|c|}{ F. } \\
\hline & Goats & Total & males & No. & No. & $\%$ & No. & $\%$ & No. & $\%$ & No. & $\%$ \\
\hline \multirow[t]{12}{*}{ Matbool } & 1 & 18 & 7 & 11 & 0 & 0.0 & 0 & 0.0 & 0 & 0.0 & 0 & 0.0 \\
\hline & 2 & 31 & 13 & 18 & 1 & 3.23 & 1 & 3.23 & 1 & 3.23 & 2 & 6.45 \\
\hline & 3 & 26 & 12 & 14 & 1 & 3.85 & 2 & 7.69 & 1 & 3.85 & 3 & 11.54 \\
\hline & 4 & 19 & 7 & 12 & 0 & 0.0 & 0 & 0.0 & 0 & 0.0 & 0 & 0.0 \\
\hline & 5 & 22 & 9 & 13 & 0 & 0.0 & 0 & 0.0 & 1 & 4.55 & 0 & 0.0 \\
\hline & 6 & 24 & 10 & 14 & 1 & 4.17 & 1 & 4.17 & 1 & 4.17 & 1 & 4.17 \\
\hline & 7 & 26 & 11 & 15 & 1 & 3.85 & 2 & 7.69 & 1 & 3.85 & 2 & 7.69 \\
\hline & 8 & 15 & 5 & 10 & 1 & 6.67 & 1 & 6.67 & 1 & 6.67 & 2 & 13.33 \\
\hline & 9 & 11 & 3 & 8 & 0 & 0.0 & 0 & 0.0 & 0 & 0.0 & 0 & 0.0 \\
\hline & 10 & 28 & 13 & 15 & 0 & 0.0 & 1 & 3.57 & 0 & 0.0 & 1 & 3.57 \\
\hline & 11 & 27 & 11 & 16 & 1 & 3.7 & 1 & 3.7 & 1 & 3.7 & 1 & 3.7 \\
\hline & 12 & 29 & 11 & 18 & 0 & 0.0 & 2 & 6.9 & 1 & 3.45 & 2 & 6.9 \\
\hline Total & 12 & 276 & 112 & 164 & $\overline{6}$ & $\overline{5.36}$ & 11 & 6.7 & 8 & 7.14 & 14 & 8.54 \\
\hline
\end{tabular}

Kafrelsheikh Vet. Med. J. Vol. 9 No. 1 (2011) 
A Seroprevalence Study Of Brucellosis In Goats ...

Table (2): Seroprevalence of brucellosis among examined flocks and animals.

\begin{tabular}{|c|c|c|c|c|c|}
\hline & \multirow{2}{*}{ No. of examined } & \multicolumn{2}{|c|}{ RBPT } & \multicolumn{2}{|c|}{ I-ELISA } \\
\hline & & $+\mathrm{Ve}$ & $\%$ & $+\mathrm{Ve}$ & $\%$ \\
\hline Flocks & 12 & 8 & 66.66 & 9 & 75.0 \\
\hline Animals & 276 & 17 & 6.16 & 22 & 7.97 \\
\hline
\end{tabular}

Table (3): Seroprevalence of brucellosis among examined goats in relation to sex.

\begin{tabular}{|c|c|c|c|c|c|c|}
\hline \multirow{2}{*}{ Test Sex } & \multicolumn{3}{|c|}{ RBPT } & \multicolumn{3}{|c|}{ I-ELISA } \\
\hline & No. of animals & $+\mathrm{Ve}$ & $\%$ & No. of animals & $+\mathrm{Ve}$ & $\%$ \\
\hline Male & 112 & 6 & 3.36 & 112 & 8 & 7.14 \\
\hline Female & 164 & 11 & 6.7 & 164 & 14 & 8.54 \\
\hline Total & 276 & 16 & 6.16 & 276 & 22 & 7.97 \\
\hline
\end{tabular}

\section{DISCUSSION}

Brucellsosis for several decades has been recognized as a significant public health problem in the Middle East and recent reports suggested that its incidence is increasing in both ruminants and humans (Benkirane, 2006; and Refai, 2002) and that currently applied control measures may not be capable of reducing the levels of infection in ruminants (Hegazy et al., 2009). Reported brucellosis prevalence in small ruminants (sheep and goats) in Sub-Saharan Africa (SSA) varied from $2.4 \%$ to $22.7 \%$ (McDermott and Arimi, 2002).

The present study showed that the prevalence of Brucella antibodies in goats was $6.16 \%$ using RBPT, and $7.97 \%$ by I-ELISA. Nada, (1982) found nearly similar results (4.7\%). Kaoud et al., (2010) found higher results $(14.5 \%)$. This difference between the prevalence of brucellosis determined by RBPT and that of I-ELISA may be attributed Kafrelsheikh Vet. Med. J. Vol. 9 No. 1 (2011) 
to the fact that I-ELISA is more sensitive in detection of IgM as well as IgG immunoglobulin Stemshorn et al., (1985). I-ELISA has been found to be more sensitive and more specific test for detection of Brucella antibodies that provides relatively accurate results. In addition, I-ELISA has been found to detect antibodies in chronically infected animals, while RBPT detects antibodies only in acutely infected subjects (Alonso et al., 1995; S' Rtmadzhiev et al., 1998; Sting and Ortmann, 2000; Ongor et al., 2001; and Cruz et al., 2002).

In the present study, the LPS were used for the development of IELISA. The LPS were used because Brucella LPS been considered the most important antigen during immune response and are the target for many serological and immunological studies. In addition, a small quantity is required for the screening of a large number of samples. According to Guarino et al., (2001), the high percentage of positivity was due to the ability of this test to detect very low levels of antibodies present in the early stage of infection, while RBPT and SAT cannot detect it. This standardized I-ELISA could be a useful diagnostic test for detection of Brucella antibodies.

It is note worthy that no single test can identify all infected animals at all stages of the disease and therefore a combination of serological tests should be included to reduce the number of both false negative and false positive serological reactions (Morgan, 1971; and Cordes and Carter, 1979).

The higher prevalence of Brucella infection detected in the present investigation could be favored by the husbandry practices in the regions and the absence disease monitoring and control policy. Goats were found 
to be at higher risk than sheep, in part due to the greater susceptibility of goats to Brucella infection than sheep and partly it is due to the fact that sheep unlike goats do not excrete the Brucella organisms for longer periods of time. The variation in prevalence between sheep and goats could be supplemented by the fact that goats which are inherently more susceptible than sheep.

There were little significant differences of the seroprevalence between male and female goats studied as it was in 112 males sera 5.36\% $(\mathrm{n}=6)$ by RBPT and 7.14\% $(\mathrm{n}=8)$ by I-ELISA, while it was in 164 females sera $6.7 \%(n=11)$ by RBPT and $8.54 \%(n=14)$ by I-ELISA. It was reported that serological response of male animals to Brucella infection is limited as it was indicated by Crawford et al., (1990), and also, testing of infected male animals were usually observed to be nonreactors or showed low antibody titers. Similarly, one research finding showed that male cattle are more resistant than females (Nicoletti, 1980).

However, the apparently higher seroprevalence figure in female animals compared to males in this study agrees with other works. (Asfaw et al., 1998); Bekele et al., 2000; and Tolosa, 2004). Further epidemiological studies and identification of the Brucella biotypes involved is recommended. The system must be able to detect early any change in incidence and prevalence. Vaccination of young animals can be combined with a test and slaughter policy in a long term action to control brucellosis in small ruminants (WHO/MZCP, 1998). It is usually accepted that a program of eliminating brucellosis by test and-slaughter policy is justified on economic grounds only when the prevalence of infected animals in an area is about $2 \%$ or less (Mustafa, and Nicoletti, 
(1993). The provision of information and education concerning the disease to farmers and local communities is essential. Climatic conditions may affect concentration patterns of herds in given areas. This prevalence according the number tested may be due to many factors such as lacking of vaccination against brucellosis and lack of effective program for eradication including periodical testing and slaughtering of reactors. The used I-Elisa indicate higher specificity and sensitivity in diagnosis of brucellosis of goats.

\section{REFERENCES}

- Abdala, A. E. D. (1966). Sudan Veterinary Science, Animal Health and Husbandry, 7, 28.

- Akakpo, A. J., and Bornarel, P. (1987). Epidémiologie des brucelloses animales en Afrique tropicale: enquêtes clinique, sérologique et bactériologique. Rev. sci. tech. Off. int. Epiz., 6: 9811027 (in French).

- Alonso, A., Rojas, X., and Guzman, E. (1995). Uso de una tecnuca de ELISA indirecto para el diagnstico de brucellosis ovina (An Indirect ELISA for the diagnosis of brucellosis in sheep). Archvos de Medicina Veterinaria, 27: 113 - 117.

- Alonso-Urmeneta, B., Marín, C., Aragón, V., Blasco, J. M., Díaz, R., and Moriyón, I. (1998). Evaluation of Lipopolysaccharides and Polysaccharides of different Epitope Structures in the Indirect Enzyme-Linked Immunosorbent Assay for Diagnosis of Brucellosis in Small Ruminants and Cattle, Clin. Diagn. Lab. Immunol. 5: 749-754. 
- Anonymous, (1986). 6èmes Journées médicales d'Abidjan 13-18 Janvier 1986 - Colloque sur les brucelloses animales et humaines Compte rendu résumé. Revue Méd. Vét., 137: 577-581 (in French).

- Asfaw, Y., Molla, B., Zessin, K. H., and Tegegn, A. (1998). A crosssectional study on bovine brucellosis and test performance in intra and peri-urban dairy production system in and around Addis Ababa. Bull Anim Health Prod Afr. 46: 217-224.

- Ayele, G. (1991). Livestock and economic differentiation in northeast Ethiopia : the Afar case. Nomadic People. 29: 10 - 20.

- Bekele, A., Molla, B., Asfaw, Y., and Yigezu, L. (2000). Bovine brucellosis in ranches and farms in southeastern Ethiopia. Bull Anim Health Prod Afr. 48: 13-17.

- Benkirane, A. (2006). Ovine and caprine brucellosis: World distribution and control/eradication strategies in West Asia/North Africa region. Small Rumin. Res., 62: 19-25.

- Blasco, J. M., Marín, C. M., Jiménez de Bagüés, M. P., Barberán, M., Hernandéz, A., Molina, L., Velasco, J., Díaz, R., and Moriyón, I. (1994b). Evaluation of allergic and serological tests for diagnosis of Brucella melitensis in sheep. J. clin. Microbiol., 32: 1835-1840.

- Charters, A. D. (1980). Brucellosis. Australian Family Physican, 9: 707-712.

- Chukwu, C. C. (1985). Brucellosis in Africa. Part I: The prevalence. Bull. Anim. Hlth. Prod. Afr. 33: 193-198. 
- Cordes, D.O. and Carter, M.E. (1979). Persistence of Brucella abortus infection in six herds of cattle under brucellosis eradication. New Zealand Veterinary Journal, 27: 255-259.

- Crawford, R. P., Huber, J. D., and Adams, B. S. (1990). Epidemiology and surveillance. In: Nielsen K, Duncan JR, eds. Animal Brucellosis. Florida: CRC Press Inc.; 131-148.

- Cruz, M. L., Wilde, O., Vega, A., and De la Samartino, L. (2002). El test ELISA en el diagnostico de la brucellosis caprina en el NOA (The ELISA test in the caprine brucellosis diagnosis in the northwest region of Argentina). Vet Argent. 188: 576 - 580.

- Díaz, R., Jones, L. M., Leong, D., and Wilson, J. B. (1968a). Surface antigens of smooth brucellae. J. Bacteriol., 96: 893-901.

- Falade, S., and Hussein, A. H. (1997). Brucella sero - activity in Somali goats. Trop Anim hlth Prod. 17: 93 - 99.

- Farina, R. (1985). Current serological methods in B. melitensis diagnosis. In : brucella melitensis. (Plommet, M., Verger, J. M., eds), Martinus Nijhoff Publ., Dordrecht, 139-146.

- Garin-Bastuji, B., and Blasco, J. M. (1997). Caprine and ovine brucellosis (excluding B. ovis infection). In : Manual of standards for diagnostic tests and vaccines, Third edition 1996, OIE, Paris, 350-368.

- Gorrell, M. D., Milliken, G. L., Anderson, B. J., and Pucci, A. (1984). An enzyme immunoassay for bovine brucellosis using a monoclonal antibody specific for field strains of Brucella abortus. Developments in Biological Standardization, 56: 491-494. 
- Greiser-Wilke, I., MacMillan, A. P., and Moennig, V. (1991). A competition enzyme immunoassay with monoclonal antibodies for the analysis of sera from cattle of two herds with suspected brucellosis. Tierarztliche-Praxis 19: 131-134.

- Guarino, A., Fusco, G., Serpe, L., Gallo, P., Di Matteo, A., Urbani, G., Tittarelli, M., Di Ventura, M., and Condoleo, R. (2001). Indirect ELISA for the diagnosis of brucellosis in water buffaloes (Bubalus bubalis) in Italy. Vet Rec 149: 88-90.

- Hegazy, Y. M., Ridler A. L., and Guitian, F. J. (2009). Assessment and simulation of the implementation of brucellosis control program in an endemic area of the Middle East. Epidemiol. Infect., 137: 14361448.

- Joint FAO/WHO, (1986). Expert Commitie on Brucellosis, Sixth Report, Technical Report Series 740, WHO, Geneva, Switzerland.

- Kaoud, H. A., Zaki1, M. M., El-Dahshan, A. R., and Nasr, S. A. (2010). Epidemiology of brucellosis among farm animals. Nature and Science, 8: 190-197.

- MacMillan, A., (1990). Conventional Serological Tests. In: Animal brucellosis. (Nielsen, K., Duncan, J.R., eds). CRC Press Inc., Boca Raton, 153-198.

- Marín, C. M., Moreno, E., Moriyón, I., Díaz, R., and Blasco, J. M. (1999). Performance of competitive and indirect ELISAs, gel immunoprecipitation with Native Hapten Polysaccharide and standard serological tests in diagnosis of sheep brucellosisClin. Diagn. Lab.Immunol. , 6: 269-272. 
- McDermott, J. J., and Arimi, S. M. (2002). Brucellosis in sub-saharan Africa: epidemiology, control and impact. Vet. Microbiol., 90: 111-134.

- Montasser, A. M., Affi, M. M., El-Bayoumy, E. M., Abdul-Raouf U. M., and Mohamad, H. A. (2011). Efficiency of Serological Tests for Detection of Brucellosis in Ruminant at South Provinces of Egypt. Global Veterinaria, 6: 156-161.

- Morgan, W. J. B. (1971). Some recent advances in the diagnosis of brucellosis. Irish Vet. J., 25: 214-221.

- Mustafa, M., and Nicoletti, P. (1993). Proceeding of the Workshop on Guidelines for a Regional Brucellosis Control Program for the Middle East. Feb. 14-17, Amman, Jordan. FAO, WHO and OIE. Doi: 10.1016/S0167-5877(03)00127-2.

- Nada, S. M. M. (1982). Further studies on caprine and ovine brucellosis microorganisms. Ph.D. Thesis, Faculty of Vet. Med., Cairo Univ.

- Nicoletti, L. P. (1980). The epidemiology of bovine brucellosis. Adv Vet Sci Comp Med. 24: 69-98.

- Nielsen, K. (2002). Diagnosis of brucellosis by serology. Vet. Microbiol., 90: 447-459.

- Nielsen, K., Cherwonogrodzky, J., Duncan, J. R., Bundle, D. R., Nicoletti, P., and Forbes, L. B. (1991). A competitive enzyme immunoassay for diagnosis of bovine brucellosis. United Nations Press, pp 131-143. ed: Frank, Julius F. Tokyo. 
- Omer, M. K., Asfaw, T., Skjerve, E., Teklegiorgis, T., and Woldehiwoz, Z. (2002). Prevalence of antibodies to Brucella spp and risk factors related to high risk occupational groups in Eritrea. Epidemiol Infect, 129: 85 - 91.

- Omer, M. K., Skjerve, E., Holstad, G., Woldehiwot, Z., and Macmillan, A. P. (2000). Prevalence of antibodies to Brucella spp in cattle, sheep, goats, horses and camels in the state of Eritrea ; influence of husbandry systems. Epidemiol Infect, 125: 447 - 453.

- Ongor, H., Muz, A., and Cetinkaya, B. (2001). Atik yapmis koyularda bruselozis' in teshisinde ELISA ile digger serolojik testlerin karsilastirilmasi (comparison of ELISA with other serological tests in the diagnosis of ovine brucellosis). Turk Veterinerlik ve Hayvancilik Dergisi, 2001: 25, 21 - 26.

- Refai, M. (2002). Incidence and control of brucellosis in the Near East region. Vet. Microbiol., 90: 81-110.

- Rylatt, D. B., Wyatt, D. M., and Bundesen, P.G. (1985). A competitive enzyme immunoassay for the detection of bovine antibodies to Brucella abortus using monoclonal antibodies. Vet. Immunol. Immunopathol., 8: 261-271.

- Shehu, L. M., Yusuf, H., Kudi, A. C., and Kalla, D. U. (1999). Seroprevalence of brucellosis in ruminants in Baunchi and environs. Nig Vet J, 20: 67 - 74 .

- Smith, C. M., and Sherman, M. D. (1996). Brucellosis. In : Goat Medicine, Baltimore, Lea and Febiger, 423 - 424. 
- Snedecor, G. W. and Cochran, W. G. (1981). Statistical Methods. $8^{\text {th }}$ ed. The Iowa State University Press. USA.

- S' Rtmadzhiev, K., Popova, T., and Masalsiki, N. (1998). Use of the ELISA assay for the diagnosis of brucellosis. Vet Med, 4: 7 - 9.

- Stemshorn, P. W., Forbes, L. B., Fagiesome, M. D., Nielsen, K. H., Robertson, F. J., and Sammagh, B. S. (1985). A comparison of standard serological tests for diagnosis of bovine brucellosis in Canada. Can. J. Comp. Med. 49: 391-394.

- Sting, R., and Ortmann, G. (2000). Erfahrungen mit einfanchen ELISA - Ttestsystemen fur die brucellose - serlogie bei Rind Schfund Zeiege (experience with a simple ELISA assay for serologic diagnosis of Brucella in cattle, sheep and goats). Berliner und Munchner Tierarztliche Wochenschrift, 113: 22 - 28.

- Sutherland, S. S., Hollander, L., and Den-Hollander, L. (1986). Comparison of an enzyme-linked immunosorbent assay using monoclonal antibodies and a complement fixation test for cattle vaccinated and infected with Brucella abortus. Vet. Microbiol.,, 12: $55-64$.

- Tolosa, T. (2004). Seroprevalence study of bovine brucellosis and its public health significance in selected sites of Jimma Zone, Western Ethiopia. MSc Thesis. Addis Ababa University, Faculty of Veterinary Medicine, Debre Zeit. Waghela, S. (1976). Animal brucellosis in Kenya: A review. Bull Anim Hlth Prod Afr, 1, 53.

- WHO/MZCP, (1998). Human and Animal Brucellosis . Report of a WHO/MZCP workshop . Damascus, Syrian Arab Republic, 4-5 May. 


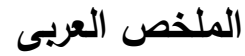

فى هذه الدراسـة، تم عمل لدراسـة معدل إصـابة الماعز بالبروسيلا سبرولوجيا خـلال الفترة من

يناير الى مايو عام 2011 بقرية منبول بمحافظة كفر الثيخ بمصرفى عدد 276 ماعز فى الاعمار اكبر من 6 شهور . تم تجميع عينات السيرم من عدد 12 قطيع غير محصنة. اجرى اختبارى الروز

بنجال والاليزا الغير مباشرة للكثف عن الأجسام المضادة فى عينات السيرم. اظهرت النتائج، بفص عدد 12 قطيع عدد 8 قطعان موجبة سيرولوجيا بنسبة 66.67\% وعدد 9 قطعان موجبة سبرولوجيا باختبارى الروز بنجال و الاليزا الغير مبانشرة على التوالى. على مستوى الحيوانات كانت النتائج للمسح السـيرولوجى الكليـة لسـيرم الهـاعز المفحوصـة وعـدها 276 هـو 6.16\% (عـد=17) و7.97\% (عد=22) باختبارى الروز بنجال و الاليزا الغير مباشرة على التوالى. كانت نتائج المسح السيرولوجي حسب الجنس غير ذات اهمية معنوية ـ بالنسبة لعدد عينات السيرم المحوصة لعدد 112 ذكر الماعز ، كانت النسبة 5.36\% (عدد=6) ونسبة 7.14\% (عدد=8) باختبارى الروز بنجال والاليزا الغير مباشرة على التوالى بينما كانت النسبة لعدد 164 عينة سيرم لانثى الماعز هو 6. 7\% ، (عدد=11) ونسبة 8.54\% (عدد=14) على التوالى. نستخلص من هذه النتائج أهميـة اختبار الاليزا الغير مباشـرة فى تشخيص مرض البروسيلا فى الماعز • 